\title{
Metal-strip bracing versus diagonal timber bracing in timber trussed tiled roofs
}

\author{
Prof WMG Burdzik \\ PrEng, MEng, PhD(Pretoria) \\ Department of Civil Engineering, University of Pretoria, Pretoria, 0001, South Africa \\ Tel: +27(12)4202746, Fax+27(12)3625218, email: walter.burdzik@up.ac.za \\ Ms SA Skorpen \\ PrEng, CEng, MIStructE, MEng \\ Department of Civil Engineering, University of Pretoria, Pretoria, 0001, South Africa \\ Tel: +27(12)4202196, Fax +27(12)3625218, email: sarah.skorpen@up.ac.za
}

\begin{abstract}
Diagonal bracing is a common method used in South Africa for the bracing of timber trussed roofs with spans of less than $9 \mathrm{~m}$. In the typical diagonally braced roof system, the brace is placed on the underside of the compression chord, which is as far as it can be placed away from the battens that brace the trusses not directly connected to the diagonal brace. Some of the stiffness of the bracing is lost because the low torsional rigidity of the top chord as well as the batten to top chord nailing is all part of the structural system. In this paper the authors investigate bracing of the entire roof system and contend that it is better to connect the bracing member closer to the battens as this improves the stiffness and bracing ability of the system. The authors study both the diagonal brace as well as the alternative bracing method that uses criss-cross metal strapping, sometimes called speed brace. The speed brace is nailed to the top of the compression chord and is therefore much closer to the battens.
\end{abstract}

Two different truss spans were studied to ascertain the buckling length of the top chord for both the diagonal bracing as well as speed bracing. By moving the bracing system closer to the battens the authors show that the speed brace gives a stiffer system which thereby reduces the buckling length of the top compression chord. 


\section{Keywords}

Timber trusses; diagonal bracing; speed bracing

\section{List of notations}

$A \quad=$ cross-sectional area

$\mathrm{d}=$ diameter of the nail in $\mathrm{mm}$

$E \quad=$ modulus of elasticity

$E I_{A B} \quad=$ stiffness of the flexural member that has the same stiffness as the nailed connection

$K=$ effective un-braced length factor

$\mathrm{K}_{\mathrm{sb}} \quad=$ stiffness of the speed brace

$K_{\text {ser }}=$ the stiffness of the nailed connection

$L \quad=$ length of the member

$L_{A B} \quad=$ distance between the centreline of the batten and the centreline of the top chord

$P \quad=$ applied load

$P_{e} \quad=$ Euler buckling load for a compression member hinged at both ends

$\rho_{\mathrm{m}} \quad=$ average density in $\mathrm{kg} / \mathrm{m}^{3}$

$\mathrm{G} \quad=$ shear modulus 


\section{Introduction}

Diagonal bracing is an accepted method in South Africa of bracing a timber trussed tiled roof with spans of less than ten metres. The battens form an integral part of the bracing, which must provide the necessary stiffness to the top chord of the truss so that the buckling length of the top chord is reduced to an acceptable length. It is of interest to note that the concrete tiles used to be nailed to the battens, but as the wind-uplift is generally less than the weight of the tiles, this is no longer done. The tiles are hooked over the battens and the friction between the tile and the batten is expected to supply some form of diaphragm action. In cases where no bracing has been used and the assumption made that the roof tiles act as a diaphragm, buckling has occurred. The slip between the battens and the tiles seems to be driven by the heating during daytime and cooling of the tiles at night. The side that starts to buckle first is the side that gets the most sun. Photograph 1 shows a roof that had no bracing and buckling of the Northern side (sunny side in the Southern Hemisphere) is clearly visible. This mode of failure occurred some years after initial erection, and is attributed to the lack of bracing. It is also interesting to note that in this case the buckling mode is not the expected S-shape, but shows that movement of the apex is also possible. The buckling can often be spotted on the tile line itself as shown in Photograph 1, but this is not always proof that something is wrong. 


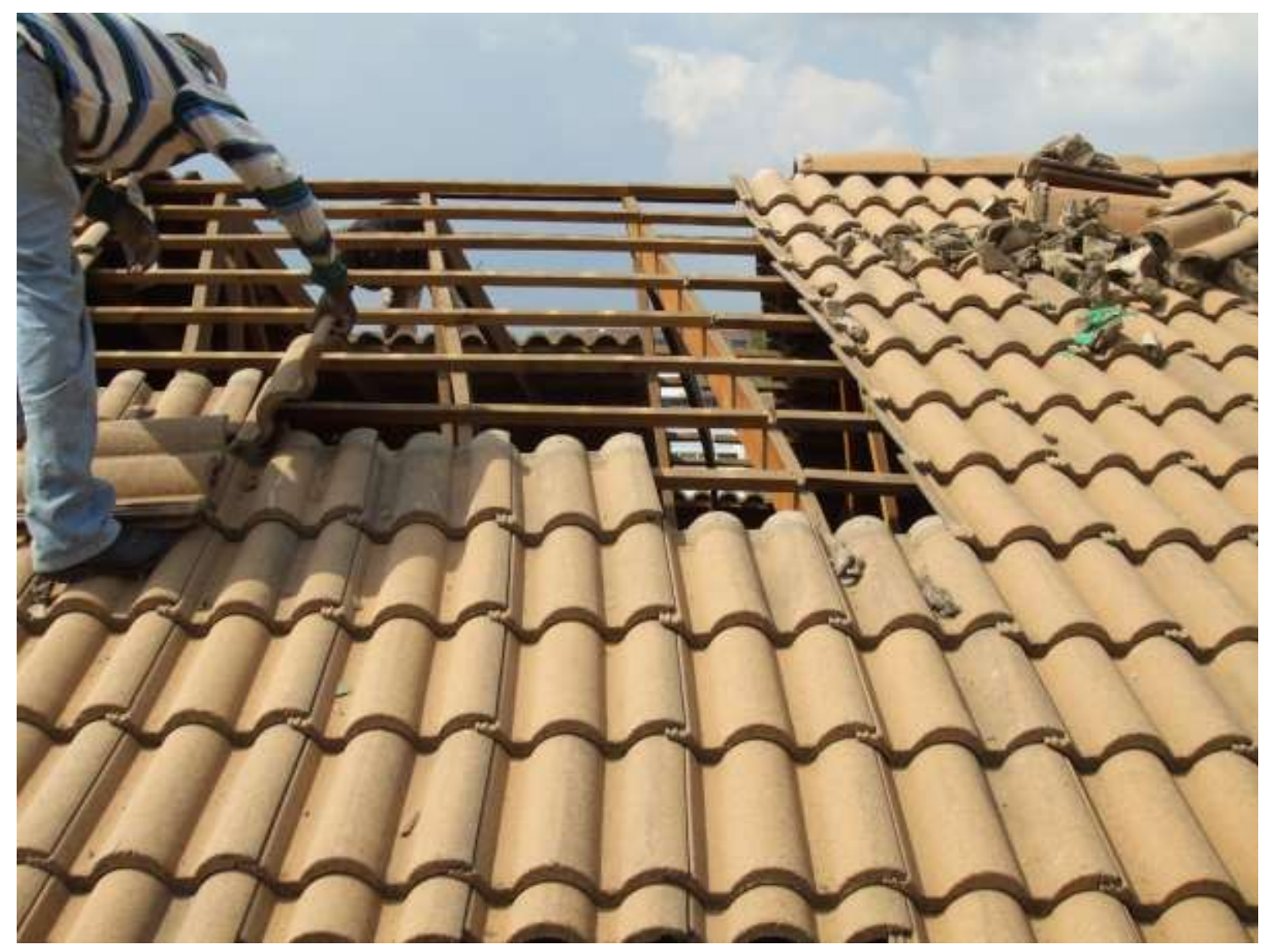

Photograph 1: This shows the buckling of the top chords of a timber trussed roof where no bracing has been supplied.

In their paper, Burdzik and Dekker, 2012,[3] contend that when a diagonal brace is used the theoretical buckling length is greater than one would expect, see Figure 1. One would expect the buckling length to be somewhere in the region of the horizontal distance between points of lateral support divided by the cosine of the pitch. However, the stiffness of the nails and the perpendicular distance between the centreline of the bracing battens and the centreline of the diagonal brace all play a part in increasing the buckling length. 


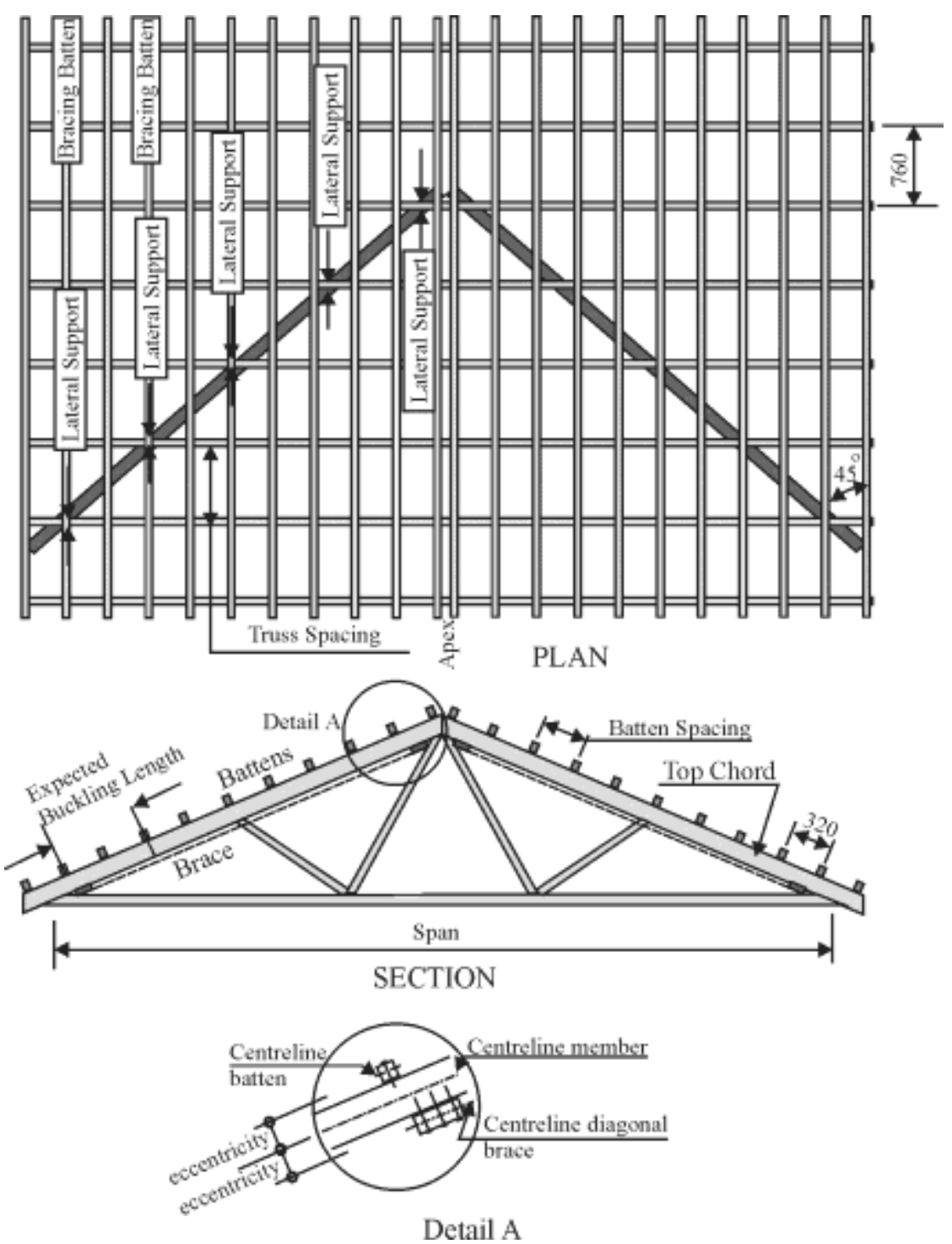

Figure 1: This figure shows the distance between the centreline of the battens (bracing members) and the diagonal brace. It also shows where possible lateral support is given to the trusses. Trusses not directly in contact with the diagonal brace are afforded lateral restraint by the battens.

The question that should then be asked is whether having the bracing member closer to the battens improves the stiffness and bracing ability of the roof system. One of the easiest methods of achieving this is by using criss-cross metal strapping, sometimes called speed brace that is nailed to the top of the compression chord. The distance between the centreline of the batten and the metal strap brace is then far less than is the case of the diagonal brace and the battens. Although the eccentricity of the bracing is reduced, the speed brace must still be strong and stiff enough to effectively reduce the buckling length (Salmon and Johnson, 1990,[8] SANS 10163:1, 2003, [10]). 
In this paper a buckling analyses on trussed roofs with diagonal bracing and then with speed bracing has been carried out in order to access the effectiveness of the two different bracing systems.

\subsection{Speed-bracing}

The metal strapping or speed brace, with dimensions of $36 \mathrm{~mm} \times 1 \mathrm{~mm}$ with punched holes for ring shank or clout nails is sold in lengths of $3,9 \mathrm{~m}$, which when installed covers 3 bays of trusses spaced at $760 \mathrm{~mm}$. Trusses are erected in the correct position and as plumb as possible. The speed brace is then installed by folding over and nailing to the side of the top chord of the first truss to be braced with the strapping being placed at more or less $45^{\circ}$ along the pitch of the roof. The strap is then nailed to intermediate trusses. At the last of the 4 trusses the bracing is once again folded over the top chord of the $4^{\text {th }}$ truss to be nailed on the side and top of the top chord. A criss-cross pattern as shown in the Figure 2 can be achieved. The battens are then placed at the correct positions and nailed to the trusses, thereby completing the triangulation of the bracing system. Once again the battens are very important members of the bracing system and should not be termed secondary members.

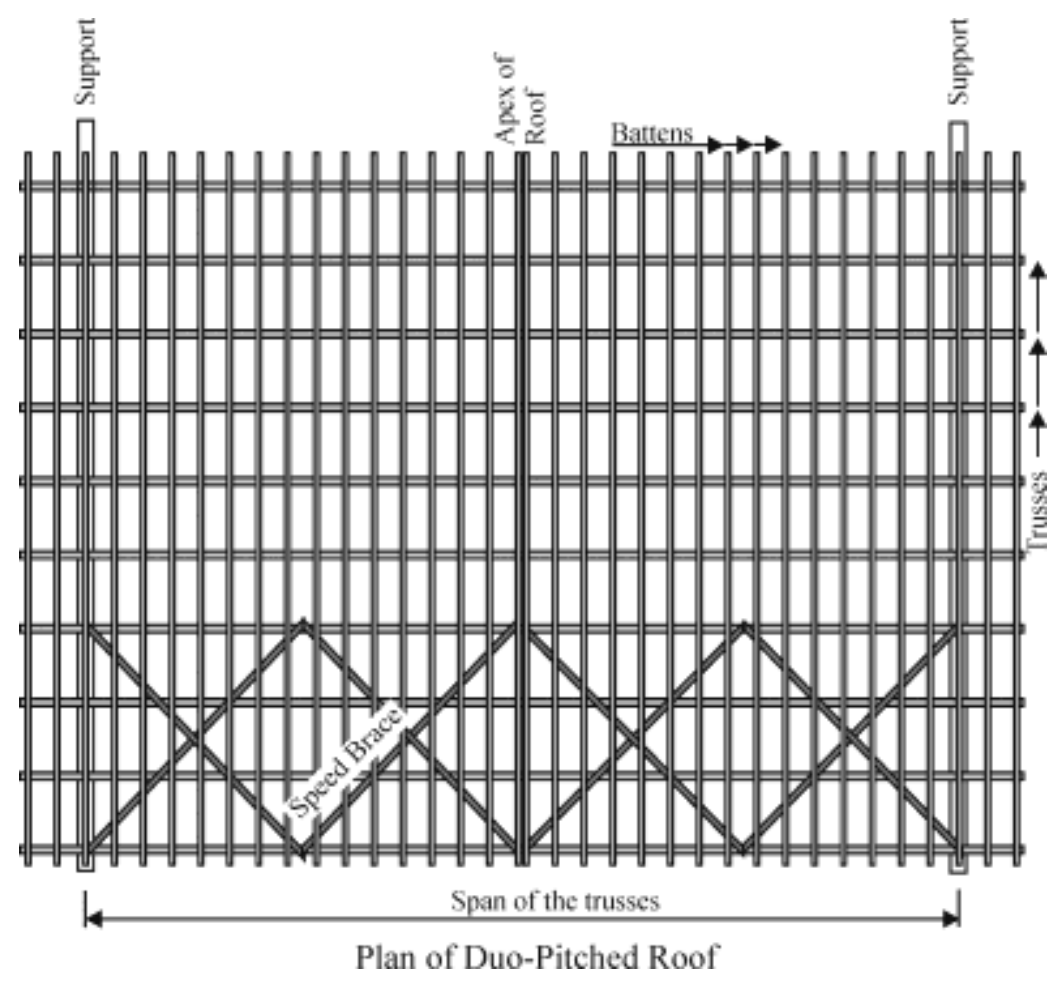

Figure 2: Speed brace installed over 3 bays, directly connected to 4 trusses. 
It is important to note that the speed brace is not necessarily connected to the trusses under a batten. They may even avoid connecting under a batten as this would cause problems with nailing of the batten. The lateral bending stiffness of the top chord is required to complete the bracing system.

\subsection{Comparison of speed bracing to conventional diagonal bracing}

Full scale testing of a braced timber roof structure is very difficult as the logistics of applying the loading is problematic. Previous attempts at full-scale testing in South Africa by tiling the roof and then applying sand bags on top of the tiles have shown that this method will not cause buckling of the top chord. The friction between the tiles and the battens leads to diaphragm action and failure of the system will not be due to buckling but rather due to overloading of one of the structural elements. Any loading must be such that the battens are able to move freely as would be the case when the friction between the tiles is broken.

A buckling analysis seems to be the most appropriate method of ascertaining whether the speed brace system offers some advantage to the stiffness of the roof system, when compared to the conventional diagonal brace system.

In order to perform a buckling analysis on the two different roof systems, connections stiffness's and member sizes and stiffness must be calculated. Requirements for each buckling analysis are summarized below:

Diagonal braced roof:

- Diagonal size and stiffness

- Nail (connection) stiffness

- Nail stiffness converted into equivalent bending member.

- Size and stiffness of truss members

Speed brace roof:

- Speed brace stiffness

- Nail (connection) stiffness 
- Nail stiffness converted into equivalent bending member.

- Size and stiffness of truss members

The calculation of the above is summarized is sections 2 and 3 . Section 4 summarizes the buckling analysis.

\section{Experimental verification of speed-brace strap and nail stiffness}

\subsection{Speed-brace stiffness}

The speed brace consists of a galvanised $1 \mathrm{~mm}$ thick by $38 \mathrm{~mm}$ wide steel strip that is punched full of holes for the nails to be fixed into the top chord of the trusses. For the analyses of the complete structure, it is necessary to have a reasonably accurate value for the stiffness of the speed brace as well as the stiffness of the nailed joint. The stiffness of the speed brace is given by:

$$
K_{s b}=\frac{A \times E}{L}
$$

Where: $\mathrm{K}_{\mathrm{sb}}=$ stiffness of the speed brace

$A=$ cross-sectional area

$E=$ modulus of elasticity

$L=$ length of the member

The stiffness of the speed brace can be reduced to an equivalent cross-sectional area to be used in the analyses.

As the stiffness of the speed brace should not vary that significantly from one test specimen to another, only two tension specimens of the speed brace were tested. A calibrated clip gauge was placed over a length of $50 \mathrm{~mm}$ to measure the elongation. Testing was done on a Materials Testing System with a capacity of $100 \mathrm{kN}$. Loading was done under deformation control as the authors were only really interested in the elastic range. Furthermore they had no wish to damage the clip gauge 
when failure occurred. The Graph 1 shows the load-elongation for a $50 \mathrm{~mm}$ long section of the test specimen 1.

A linear regression was applied to the linear portion of the graph to obtain the stiffness of the speed brace. A stiffness of $91119 \mathrm{kN} / \mathrm{m}$ was obtained. With a clip gauge length of $50 \mathrm{~mm}$ and an assumed modulus of elasticity of $206 \mathrm{GPa}$ the equivalent area of $22 \mathrm{~mm}^{2}$ could be calculated. The equivalent area of Specimen 2 was found to be $25 \mathrm{~mm}^{2}$. This means that by punching the holes in the speed brace about $40 \%$ of the stiffness is lost.

\subsection{Nail stiffness}

The stiffness of smooth and ring shank nails was tested by nailing steel strips to either side of a timber block and measuring the displacement of the nail heads relative to each other (slip), see photograph 2. The speed-brace is placed at more or less $45^{\circ}$ on site enabling 2 to 3 ring shank nails to be fixed into the top chord. Eurocode 5 [7] makes no distinction between the stiffness of nails where loading is perpendicular or parallel to the grain. The specimens were placed in such a way that loading was parallel to the grain. A total of 10 specimens in low to medium density timber (desity of $450 \mathrm{~kg} / \mathrm{m}^{3}$ ) were tested for stiffness (see Table 1). The loading was done under deflection control as only the linear portion of the load-deflection graph was required for the analyses of the roof structures. 


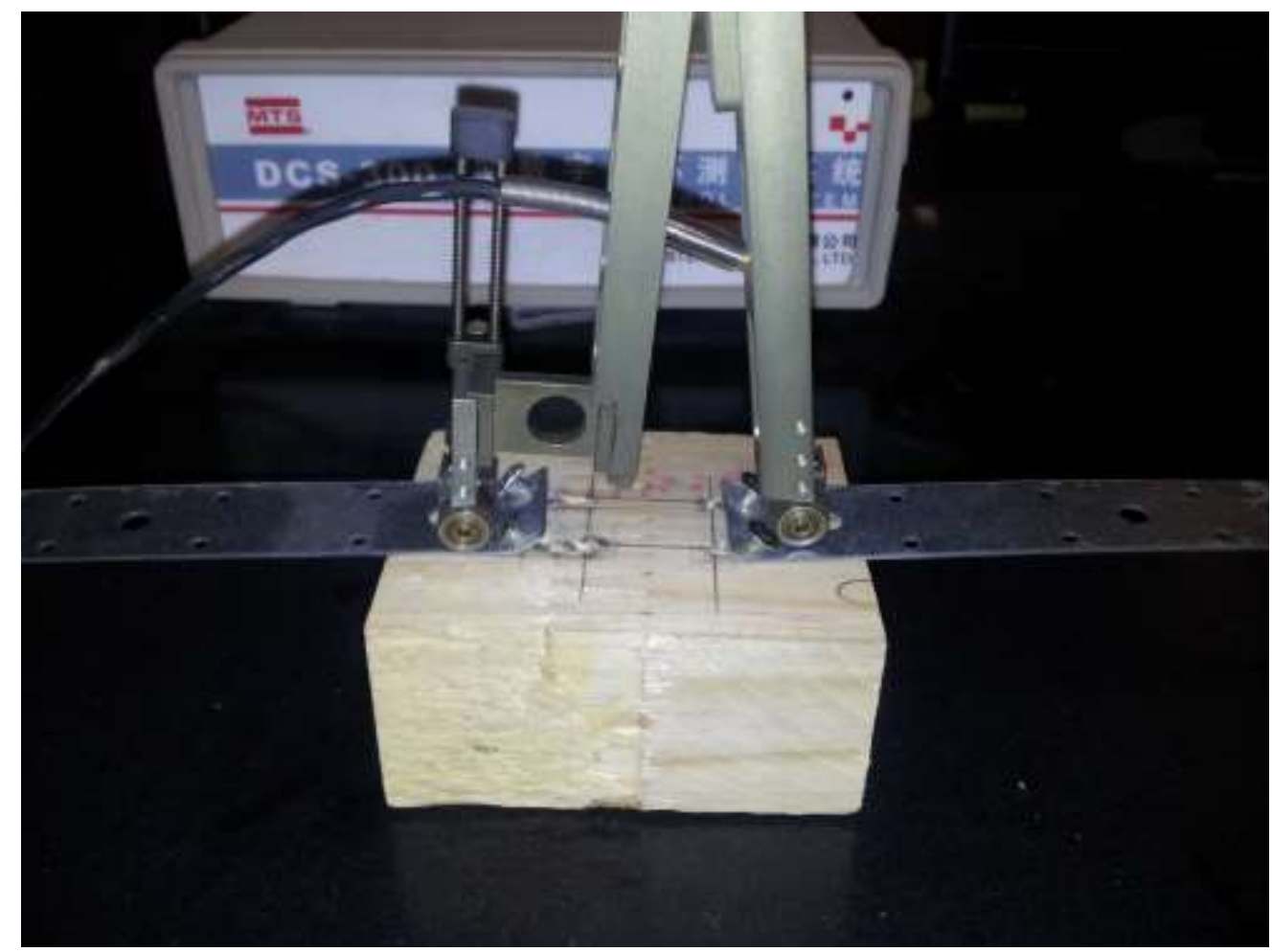

Photograph 2: This shows the double sided test specimen with two nails per side and the clip gauge straddling the connection.

\section{Specimen 1 \\ Smooth Clout Nail}

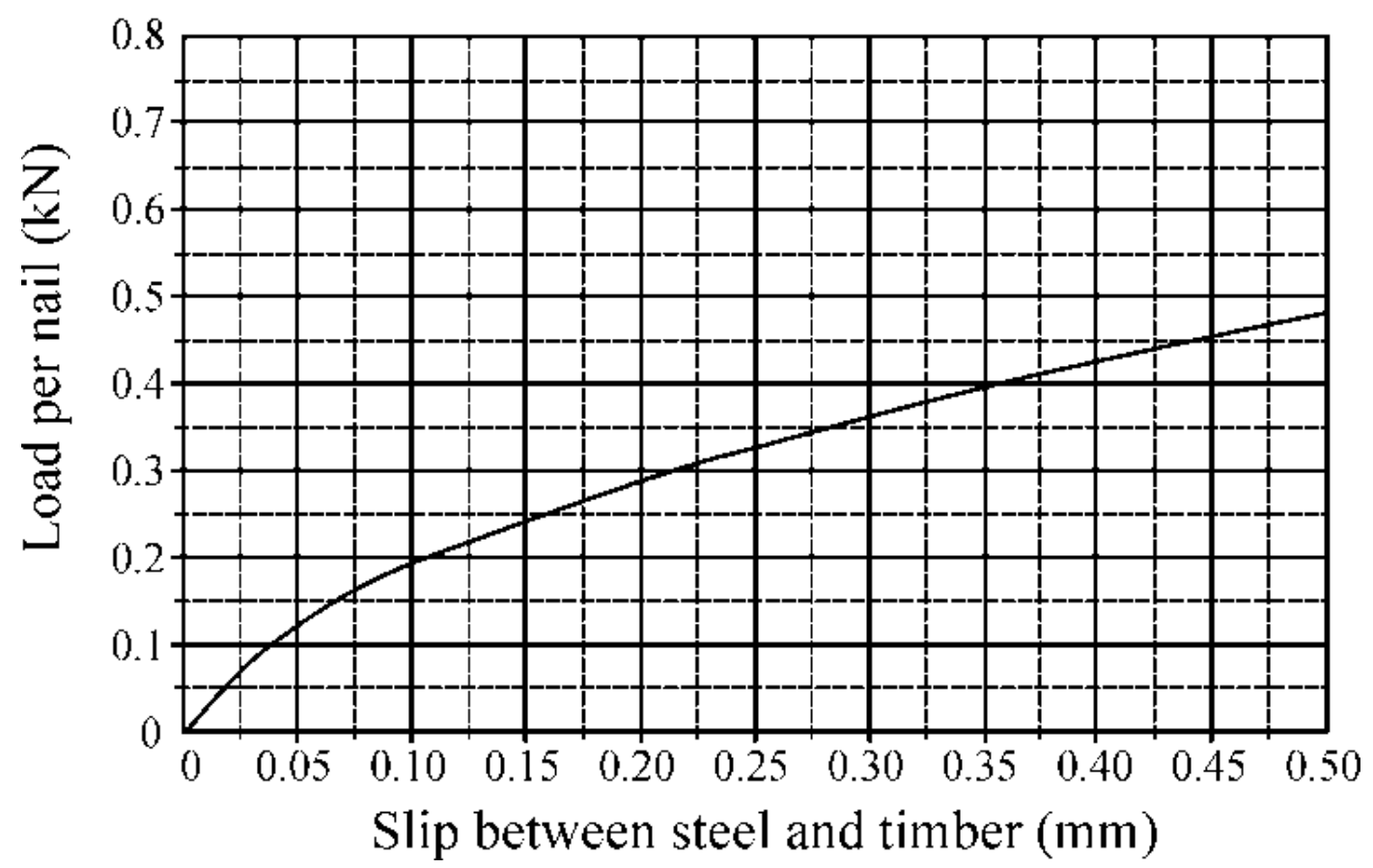

Graph 2: Typical load-slip for single smooth clout nail in shear, loading parallel to the grain. Slip is the average displacement of the nail heads relative to each other over the double sided connection. 
Specimen 3

Ring Shank Nail

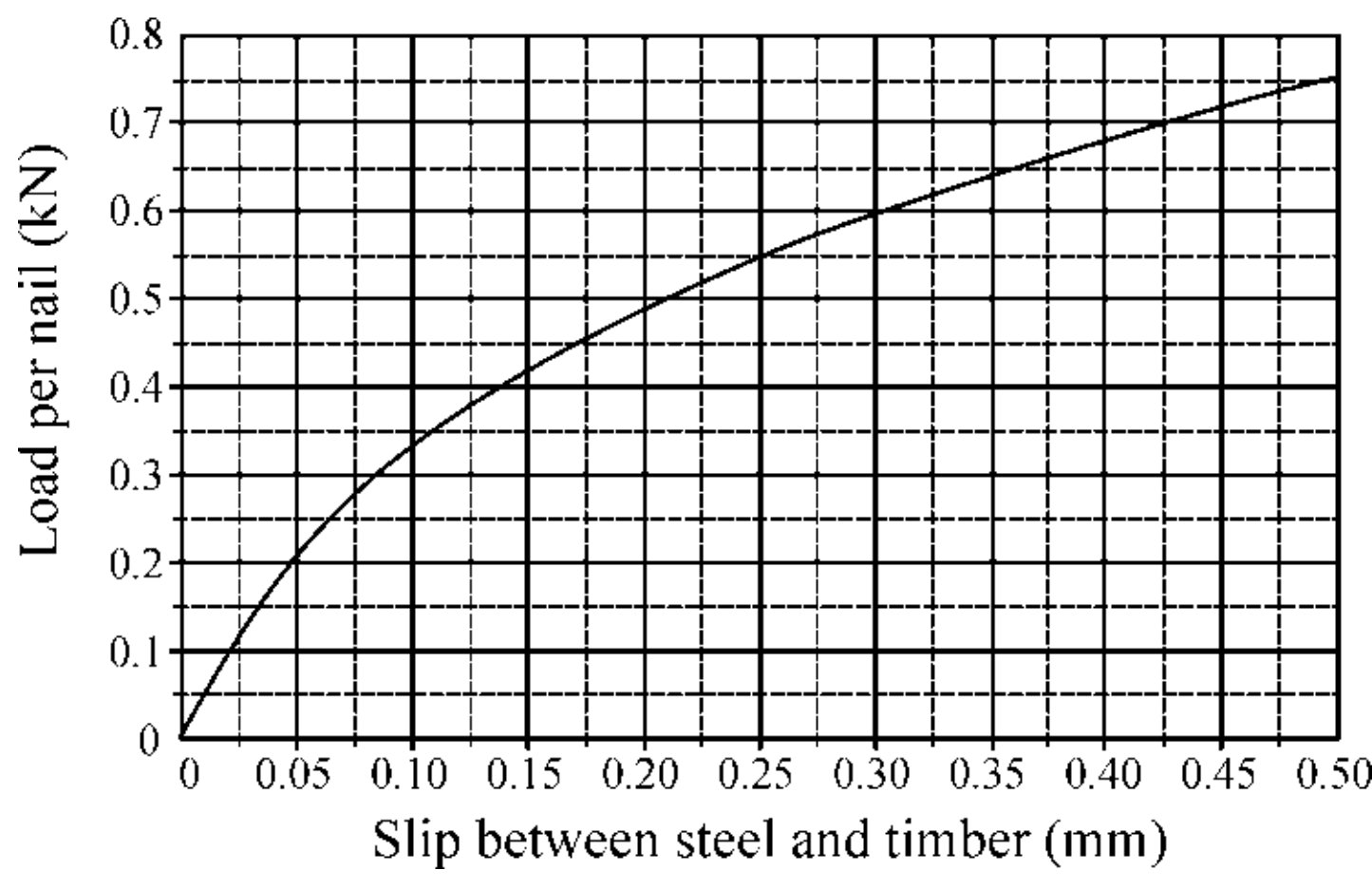

[Insert

Graph 3]

Graph 3: Typical load-slip for single ring shank nail in shear, loading parallel to the grain. Slip is the average over the double sided connection. 


\begin{tabular}{|c|c|}
\hline \multicolumn{2}{|c|}{ Smooth Nails } \\
\hline Spec & $\begin{array}{c}\text { Stiffness } \mathrm{kN} / \mathrm{mm} \\
\text { per nail }\end{array}$ \\
\hline 1 & 2.328 \\
\hline 2 & 0.883 \\
\hline 3 & 4.642 \\
\hline 4 & 2.590 \\
\hline 5 & 1.155 \\
\hline 6 & 4.675 \\
\hline 7 & 2.857 \\
\hline 8 & 4.907 \\
\hline 9 & 2.038 \\
\hline 10 & 2.476 \\
\hline Mean & 2.855 \\
\hline $5 \%$ & 1.006 \\
\hline Eurocode & 1.532 \\
\hline
\end{tabular}

\begin{tabular}{|c|c|}
\hline \multicolumn{2}{|c|}{ Ring Shank Nails } \\
\hline Spec & $\begin{array}{c}\text { Stiffness } \mathrm{kN} / \mathrm{mm} \text { per } \\
\text { nail }\end{array}$ \\
\hline 11 & 4.554 \\
\hline 12 & 3.524 \\
\hline 13 & 3.645 \\
\hline 14 & 1.934 \\
\hline 15 & 1.758 \\
\hline 16 & 1.810 \\
\hline 17 & 2.469 \\
\hline 18 & 2.776 \\
\hline 19 & 2.373 \\
\hline 20 & 3.435 \\
\hline Mean & 2.828 \\
\hline $5 \%$ & 1.781 \\
\hline Eurocode & 1.532 \\
\hline
\end{tabular}

Table 1: Short duration stiffness of smooth and ring shank nails through the metal brace into timber.

It is noted that there is a very small difference between the average stiffness of a smooth nail and a ring shank nail when they are tested in shear.

The Eurocode 5 equation for stiffness of a nailed timber to timber connection is given by the equation:

$$
k=\rho^{1,5} \times d^{0,8} / 30
$$

Where: $k=$ stiffness of the connection in $\mathrm{N} / \mathrm{mm}$ or $\mathrm{kN} / \mathrm{m}$

$$
\begin{aligned}
& \rho=\text { density of the wood in } \mathrm{kg} / \mathrm{m}^{3} \\
& d=\text { diameter of the nail in } \mathrm{mm}
\end{aligned}
$$


To obtain the stiffness through a steel plate the value obtained from the equation is multiplied by 2 . As limited tests have been done using SA pine to validate the Eurocode 5 stiffness for timber-to-timber connections, the authors were curious to see whether the same applied for nails into SA pine through a $1 \mathrm{~mm}$ thick bracing strap.

For a $3 \mathrm{~mm}$ nail into $450 \mathrm{~kg} / \mathrm{m}^{3}$ pine, the stiffness for a timber-to-timber connection would be $766 \mathrm{~N} / \mathrm{mm}$ and for a steel-to-timber connection double that, i.e. $1532 \mathrm{~N} / \mathrm{mm}$.

The tests show that the Eurocode 5 equation may be conservative for the steel to timber connection in SA pine.

There is great variability in the stiffness of the nail-wood connection but it will be shown that this should not influence the outcome of the buckling analyses unduly. In this paper the stiffness of the metal strap to timber nailing was varied in the analyses between $100 \%$ and $50 \%$ of the short duration stiffness to illustrate the influence on the buckling length.

\subsection{Conversion of nail stiffness to an equivalent bending member for analysis} purposes.

Two nail stiffnesses are important in the analysis of a complete speed-braced roof structure, namely the batten to top chord connection and then the speed-brace to top chord connection. The two nailed connections have a different flexural shape as tests have shown that the nail in the batten to top chord connection go into double flexure whereas the authors assumed that the nail in the speedbrace to top chord goes into single flexure after observing the results of the testing of the nail stiffness. The deflected shape of the batten to top chord connection is given in Figure 3. The equivalent batten to top chord connection member can be obtained from basic principles shown by Burdzik (2006) [2] and is given by the following equation:

$$
E I_{A B}=\frac{K_{s e r} \times L_{A B}^{3}}{12}
$$




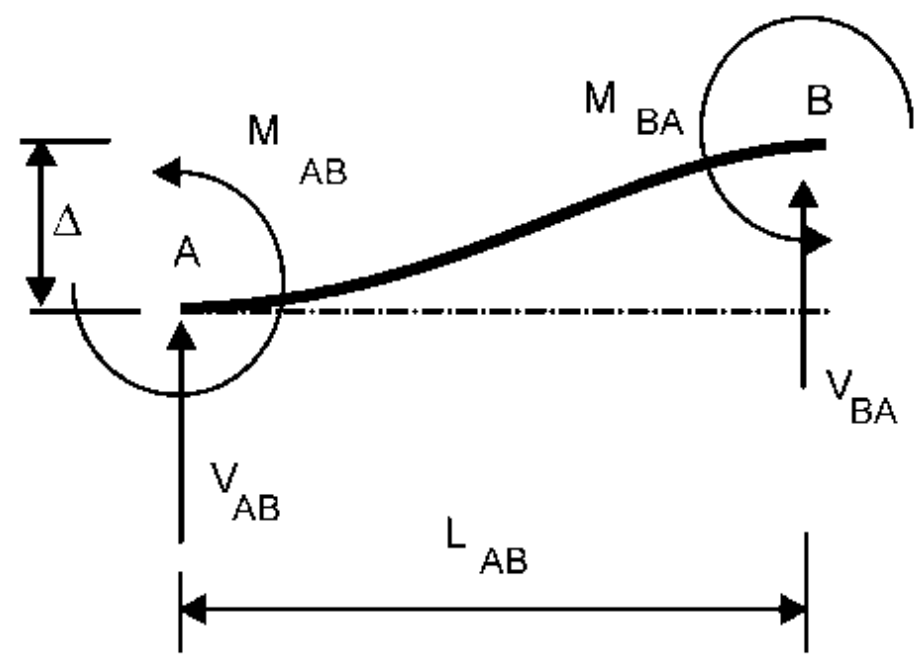

Figure 3: Deflected shape of the flexural member that was used when modelling the batten to top chord nail connection in a centreline frame analysis.

Where:

$E I_{A B}=$ stiffness of the flexural member that has the same stiffness as the nailed connection $L_{A B}=$ distance between the centreline of the batten and the centreline of the top chord $K_{\text {ser }}=$ the stiffness of the nailed connection.

The assumed deflected shape of the speed-brace to top chord connection is given in Figure 4. The equivalent flexural member can be determined from basic principles obtained from the slope deflection equations in Coats et al, 1988 [5].

$V_{B A}=\frac{-M_{A B}}{L_{A B}}=\frac{3 E I_{A B} \times \Delta}{L_{A B}^{3}}$

But $V_{A B} / \Delta$ is equal to the stiffness of the nail, $K_{\text {ser }}$.

The required flexural stiffness El can be calculated as follows:

$E I_{A B}=\frac{K_{s e r} \times L_{A B}^{3}}{3}$ 


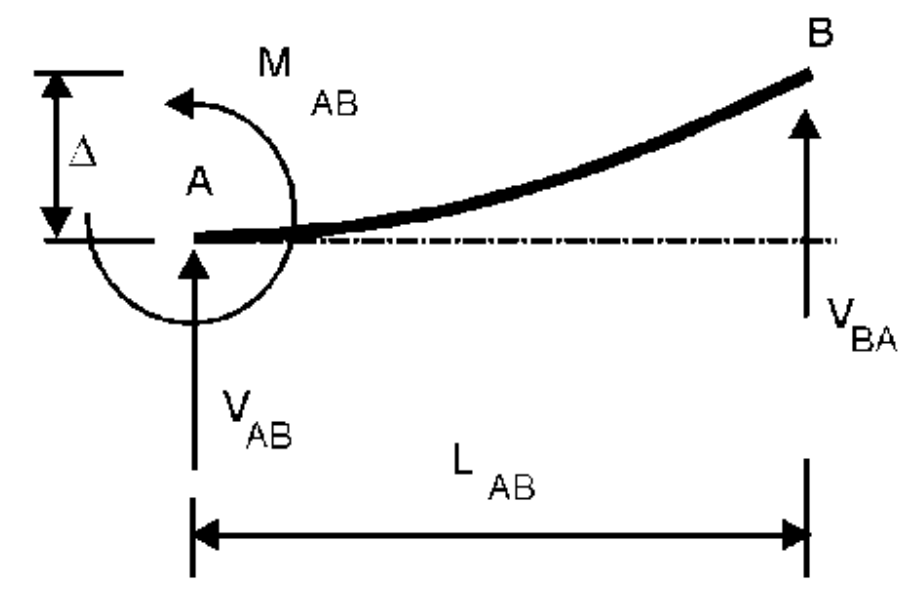

Figure 4: Deflected shape of the flexural member that was used when modelling the speed-brace to top chord connection in a centreline frame analysis

\section{Analyses and sizing of typical roof trusses}

The South African Limit-states timber design code, SANS10163:1 (2003) [10], does not cover the use of speed brace and it is left to the discretion of nail plate system suppliers to decide on the effective, or buckling length of the braced top chord. SANS10163:2 (2001) [11] does prescribe a minimum effective length of 15 times the lateral dimension. As the majority of trusses manufactured in South Africa use $36 \mathrm{~mm}$ wide timber, this translates into an effective length of $540 \mathrm{~mm}$.

The authors undertook centreline matrix-stiffness analyses of 2 tiled roof spans, namely $12 \mathrm{~m}$ and $9 \mathrm{~m}$ with a pitch of $26^{\circ}$ with $650 \mathrm{~mm}$ overhangs. Top and bottom chords were assumed to be continuous although in many cases the bottom chord is spliced. The $9 \mathrm{~m}$ span is commonly used in South Africa and the $12 \mathrm{~m}$ span is too large for the use of diagonal bracing (SANS 10243, 2004). Trusses were spaced at $760 \mathrm{~mm}$ with the mass of the tiles, together with the battens assumed as $50 \mathrm{~kg} / \mathrm{m}^{2}$, and the mass of the ceiling taken as $10 \mathrm{~kg} / \mathrm{m}^{2}$ respectively. The analyses were simplified by assuming centreline connectivity of the members with the top and bottom chord being continuous and the web members pinned at the ends. 
Figure 5 and 6 gives the resultant forces and bending moments in the members after the permanent loads. i.e. tiles, battens, ceiling and timber, (dead loads) and the imposed (live) load of $0,4 \mathrm{kN} / \mathrm{m}^{2}$ have been multiplied by load factors of 1,2 and 1,6 respectively.

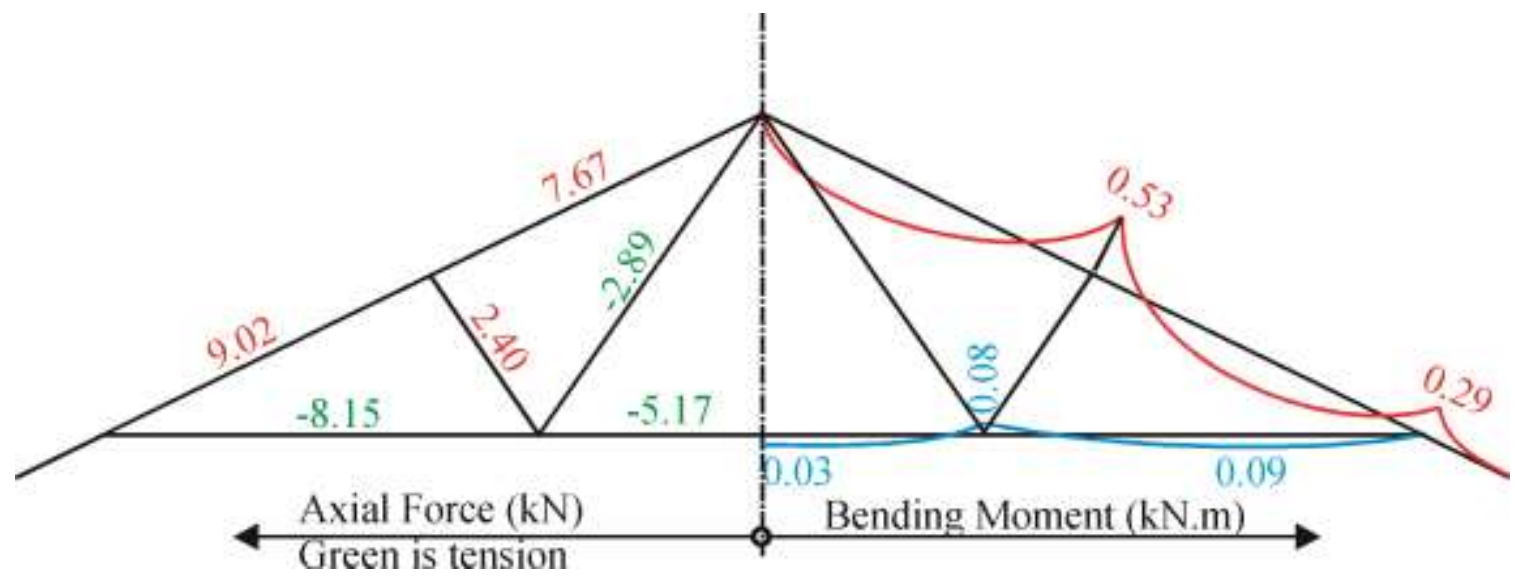

Figure 5: Ultimate forces and bending moments in a $9 \mathrm{~m}$ span W truss (Fink truss) with tiles as roofing material and a light-weight ceiling. Imposed loading in accordance with SANS10160, (2001) [13]

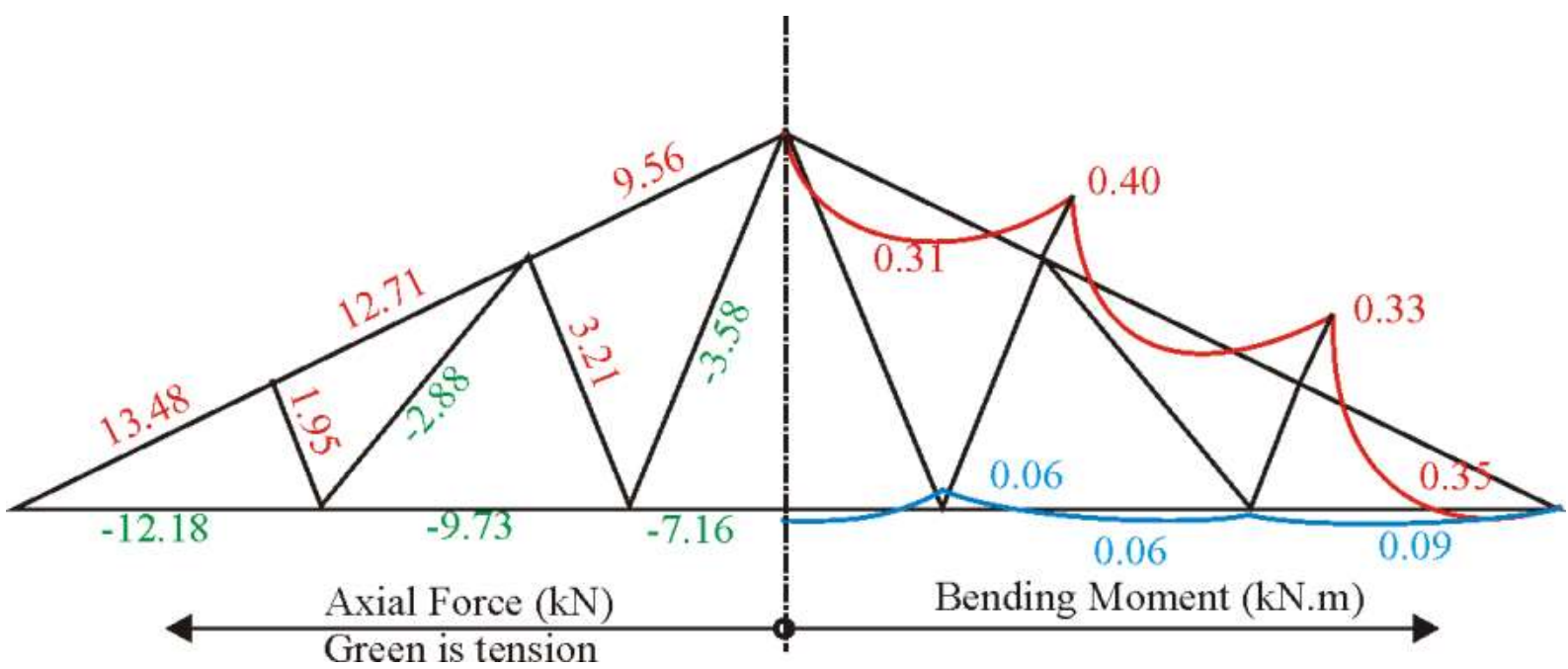

Figure 6: Ultimate forces and bending moments in a $12 \mathrm{~m}$ span WW truss with tiles as roofing material and a light-weight ceiling. Imposed loading in accordance with SANS10160, (2001) [13]

Members of the $12 \mathrm{~m}$ and $9 \mathrm{~m}$ roof trusses were then sized in accordance with SANS10163:1 (2003)

[10] assuming the effective length of the top chord to be $540 \mathrm{~mm}$. The Table 2 gives the sizes and the 
material properties that resulted, with member buckling at ultimate limit state being the governing criterion. The minimum generally accepted size of the top and bottom chords and web members is $36 \mathrm{~mm} \times 111 \mathrm{~mm}$ and $36 \mathrm{~mm} \times 73 \mathrm{~mm}$, Grade 5 timber, respectively.

\begin{tabular}{|c|c|c|c|c|}
\hline Member & $\mathbf{b}(\mathbf{m m})$ & $\mathbf{h}(\mathbf{m m})$ & $\begin{array}{c}\text { Modulus of elasticity } \\
(\mathbf{M P a}) \text { Grade 5 S A pine }\end{array}$ & $\begin{array}{c}\text { Shear modulus } \\
\text { MPa }\end{array}$ \\
\hline Top chords & 36 & 111 & 7800 & 600 \\
\hline Bottom chord & 36 & 111 & 7800 & 600 \\
\hline Webs & 36 & 73 & 7800 & 600 \\
\hline Battens & 36 & 36 & 7800 & 600 \\
\hline Diagonal brace & 36 & 111 & 7800 & 600 \\
\hline
\end{tabular}

Table 2: Sizes of members of the $9 \mathrm{~m}$ and $12 \mathrm{~m}$ span trusses designed in accordance with SANS10163:1 (2003) [10]

\section{Buckling Analyses of the Roofs}

A buckling analysis on a $9 \mathrm{~m}$ and $12 \mathrm{~m}$ timber trussed roof with diagonal bracing and then with speed bracing has been carried out in order to access the effectiveness of the two different bracing systems. The same stiffness of the timber members (see table 2) and their connectors (see table 3 ) has been used in the analysis. Prokon (2012), analysis software used by most Engineers in South African, was used for the buckling analysis. This section describes the important factors influencing the buckling analysis, and a sketch of the model is shown in Figure 7.

\subsection{Modulus of Elasticity of Compression Members}

When buckling occurs in a roof where the trusses are connected by battens, all the trusses will move in the same direction, (sympathetic buckling), as illustrated in Figures 7 and 8 . The lateral stiffness of the system will then tend towards the mean stiffness of all the compression members in the roof. One would assume that this would also reflect the mean stiffness of a given grade of timber. If the selection of the timber is such that the modulus of elasticity is on the low side of the population, the 
buckling analyses would reflect the lower modulus of elasticity (MOE) by showing an increase in the buckling length. In this paper, the authors have assumed that the mean modulus of elasticity represents the specified grade population.

The mean modulus of elasticity is used, rather than the characteristic value, as the mode of failure is sympathetic buckling, in which the less stiff members are helped by the more stiff members. The effect is that the stiffness of the roof tends towards the mean value.

\subsection{Boundary Conditions}

Symmetry of the roof under permanent loading allows for the half structure to be analysed. This makes it easier and less time consuming to model the structure. The position of the centreline of the battens and the bracing strap relative to the centreline of the top chord should be taken into account.

Trusses are usually supported on wall plates and the space between the trusses filled with brickwork. The authors felt that it is reasonable to assume that rotation about the $\mathrm{X}$-axis and that translation in the $\mathrm{Y}$ - and Z-directions are prevented at the support (see Figure 7). For the half-structure, the apex is supported in the X-direction with a rotational spring about the $\mathrm{Y}$-axis. The rotational spring will have the stiffness of the nail plates at the apex. The bottom chord is supported in the X-direction and is fixed for moments about the Z- and Y-axes.

As the web members are connected by nail plates the authors were of the opinion that for buckling the stiffness about the X-axis is important, so the web members were fully fixed to the chords in the analyses.

As the bracing members have very small second moment of area about the X-axis and would therefore buckle under compression loading, they were analysed as tension only members. 


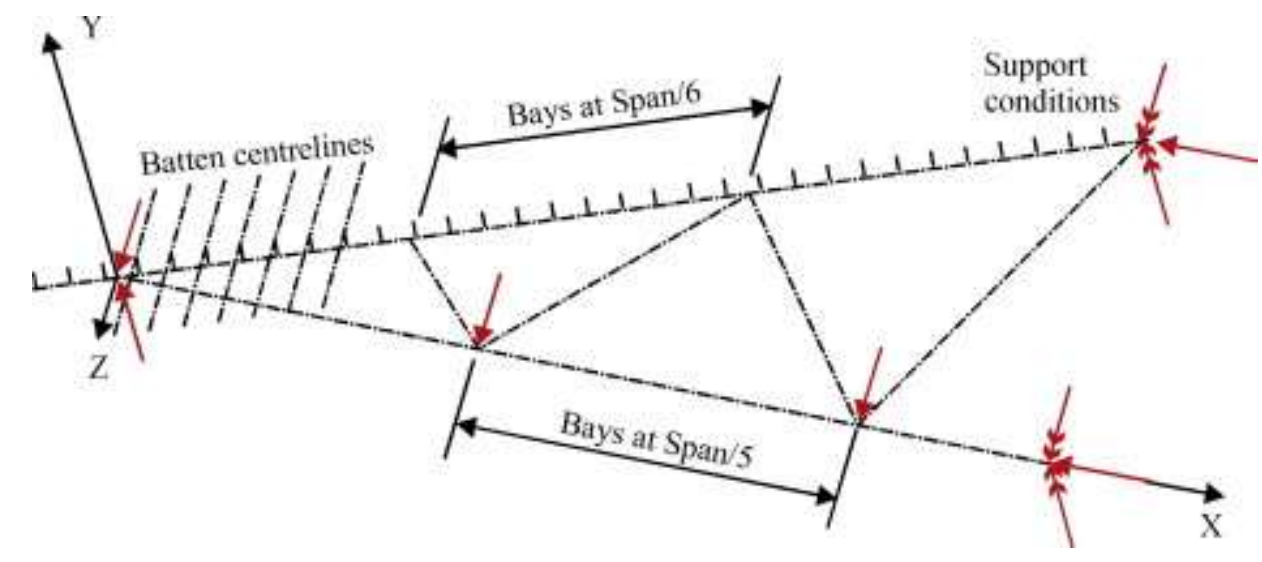

Figure 7: This shows the half-structure and the direction of the axes. Note that the centreline of the battens and the top chord are displaced by the actual distance.

\subsection{Shear Modulus of Top and Bottom Chords}

It is accepted that the shear modulus of South African pine is about equal to MOE/13, Burdzik \& Nkwera (2003) [4]. Not all software packages have the facility to input the shear modulus. Prokon (2012) [9], the package used in the following analyses uses a Poisson Ratio, v, of 0.2. The shear modulus is then calculated from the following equation:

$G=\frac{E}{2(1+v)}=\frac{E}{2(1+0.2)}=\frac{E}{2.4}$

In order to ensure that the correct shear modulus of E/13 is used the St Venants torsional constant needs to be adjusted as shown below.

$$
\begin{aligned}
& G J==\frac{E J}{2.4}=\frac{E}{13} J_{\text {new }} \\
& J_{\text {new }}==\frac{13 J}{2.4}=5.42 J
\end{aligned}
$$

By decreasing the St Venant torsional constant of the top and bottom chords by 13/2.4 $=5.42$ we ensure that the correct JG is used. 


\subsection{Nail Stiffness - batten to top chord}

Eurocode 5 [7] allows a method whereby the short term stiffness of nails, that connect two pieces of timber together, may be calculated. The short term stiffness of a nail without pre-drilling, to be used for the batten to top chord connection, is given by:

$$
K_{s e r}=\frac{\rho_{m}^{1,5} \times d^{0,8}}{30}
$$

Where: $\mathrm{K}_{\text {ser }}=$ connector stiffness in $\mathrm{kN} / \mathrm{m}$

$$
\begin{aligned}
& \rho_{\mathrm{m}}=\text { average density in } \mathrm{kg} / \mathrm{m}^{3} . \\
& \mathrm{d}=\text { diameter of the nail in } \mathrm{mm} .
\end{aligned}
$$

This equation has been found, by a number of tests performed by Bosch (2001) [1] at the University of Pretoria, to represent the stiffness of nails in South African pine fairly well. The stiffness of a connection using a $3,2 \mathrm{~mm}$ nail in timber with an average density of $450 \mathrm{~kg} / \mathrm{m}^{3}$ will be about $800 \mathrm{kN} / \mathrm{m}$. To obtain the member size that connects the batten to the top chord that will replace the nail, but still have the same stiffness, Equation (2) may be used. The distance between the centrelines of the $36 \mathrm{~mm} \times 36 \mathrm{~mm}$ battens and the $36 \mathrm{~mm} \times 111 \mathrm{~mm}$ top chord is $73,5 \mathrm{~mm}$. The modulus of elasticity of steel was taken as $200 \mathrm{GPa}$. The equivalent second moment of area of the member is then (see equation 2 - double curvature):

$$
I_{A B}=\frac{K_{s e r} \times L_{A B}^{3}}{E \times 12}=\frac{800 \times 0,0735^{3}}{200 \times 10^{6} \times 12}=1,324 \times 10^{-10} \mathrm{~m}^{4}
$$

Alternatively this translates into a member with a diameter of $7,2 \mathrm{~mm}$, which was used in the buckling analysis. 


\subsection{Nail Stiffness - Speed-brace fixing}

It was assumed that the speed-brace may only have 2 nails securing it to the top chord. The stiffness of the connection can also be based on the mean value rather than the fifth percentile. The stiffness of the connection is then $2 \times 2,8 \mathrm{kN} / \mathrm{m}=5.6 \mathrm{kN} / \mathrm{m}$. The distance between the centreline of the speedbrace and the top chord is $56 \mathrm{~mm}$. The equivalent second moment of area of the member is then (see equation $4-$ single curvature):

$$
I_{A B}=\frac{K_{s e r} \times L_{A B}^{3}}{3 \times E}=\frac{5600 \times 0,056^{3}}{3 \times 200 \times 10^{6}}=16,39 \times 10^{-10} \mathrm{~m}^{4}
$$

Alternatively this translates into a member with a diameter of $13.5 \mathrm{~mm}$.

The difference between using short and long term nail stiffness is not that great, as can be seen in Table 4 and 5.

\section{Interpretation of Buckling Analysis}

A buckling analysis presents the designer with a lambda load factor, which is a factor with which the loads may increase before Euler buckling of the system will occur. The significance of an elastic buckling analysis is that the value of $\lambda_{c r} P$, the elastic buckling load of the critical member or portion of a structure or of the structure as a whole, can be determined. Dekker \& Burdzik 2005 [6] have shown that in order to calculate the elastic buckling load, and therefore the factored resistance of the critical member, the following procedure may be followed:

Calculate the equivalent effective un-braced length from the relationship:

$$
\lambda_{c r} P=\frac{\pi^{2} E I}{(K L)^{2}}
$$

Therefore: 


$$
\begin{gathered}
K L=\sqrt{\frac{\pi^{2} E I}{\lambda_{c r} P}} \\
\text { Or } \\
K=\sqrt{\frac{P_{e}}{\lambda_{c r} \cdot P}}
\end{gathered}
$$

where: $P_{e}=$ Euler buckling load for a compression member hinged at both ends.

$$
P=\text { applied load }
$$

$K=$ effective un-braced length factor

\subsection{Loading}

Buckling of a tiled roof is a permanent loading problem as the imposed load is of short duration. An imposed load would increase the friction between the tiles leading to diaphragm action by the tiles. Buckling occurs when the tiles are able to move over one another. Permanent loading would consist of the tiles, the timber and the ceiling. The permanent load is assumed to be applied instantaneously.

In the analyses undertaken for this study the tiles together with battens were taken as having a weight of $0,5 \mathrm{kN} / \mathrm{m}^{2}$, the ceiling $0,12 \mathrm{kN} / \mathrm{m}^{2}$ and the timber a density of $450 \mathrm{~kg} / \mathrm{m}^{3}$. Spacing of the trusses was $0,76 \mathrm{~m}$ with a pitch of $26^{\circ}$.

\subsection{Results of the Analyses}

The stiffness of the speed-brace to top chord connection was varied to ascertain the sensitivity on the buckling length. Three stiffnesses were chosen namely, 100\%, $75 \%$ and $50 \%$ of short duration stiffness. Table 3 shows the second moment of area required of a member to obtain the stiffness. 


\begin{tabular}{|c|c|c|c|}
\hline $\begin{array}{c}\text { Percentage of short } \\
\text { duration mean nail } \\
\text { stiffness }\end{array}$ & $\begin{array}{c}\text { Mean Stiffness Value of } \\
\text { two nails (See Table 1) }\end{array}$ & $\begin{array}{c}\text { Second moment of Area } \\
\text { of equivalent member } \\
I_{A B}=\frac{K_{s e r} \times L_{A B}^{3}}{3 \times E}\end{array}$ & $\begin{array}{c}\text { Equivalent Diameter of } \\
\text { equivalent member }\end{array}$ \\
\hline $100 \%$ & $\mathrm{kN} / \mathrm{mm}$ & $\mathrm{m}^{4}$ & $\mathrm{~mm}$ \\
\hline $75 \%$ & 5.6 & $16.39 \times 10^{-10}$ & 13.5 \\
\hline $50 \%$ & 4.2 & $12.29 \times 10^{-10}$ & 12.6 \\
\hline
\end{tabular}

Table 3: Stiffness variation in the connection between the speed-brace and the top chord.

The two spans that were considered were $9 \mathrm{~m}$ and $12 \mathrm{~m}$, however, with a constant pitch of $26^{\circ}$. The loading as described was applied and the buckling analyses were performed so that the buckling load factor, $\lambda$, could be obtained. The value of the buckling load factor, $\lambda_{c r}$, the average force in the compression member and the buckling length are given in Table 4 for the $9 \mathrm{~m}$ span roof and in Table 5 for the $12 \mathrm{~m}$ span roof and a buckling length of the top chord of the truss calculated. The buckling length of the top chord when the roof is braced with speed bracing was less than the when diagonal bracing was used.

\begin{tabular}{|c|c|c|c|c|c|}
\hline $\begin{array}{l}\text { Percentage of short } \\
\text { duration mean nail } \\
\text { stiffness }\end{array}$ & $\begin{array}{c}\text { Lambda, } \lambda_{\text {cr }} \\
\text { Speed } \\
\text { brace }\end{array}$ & $\begin{array}{l}\text { Lambda, } \\
\lambda_{\mathrm{cr}} \\
\text { Diagonal } \\
\text { brace }\end{array}$ & $\begin{array}{c}\text { Force in } \\
\text { compression } \\
\text { member, } \mathrm{P} \\
(\mathrm{kN})\end{array}$ & $\begin{array}{c}\text { Top chord buckling } \\
\text { Length, } \mathrm{KL}(\mathrm{mm}) \\
\text { Speed Brace } \\
K L=\sqrt{\frac{\pi^{2} E I}{\lambda_{c r} P}}\end{array}$ & $\begin{array}{l}\text { Top chord buckling } \\
\text { Length, KL (mm) } \\
\text { Diagonal bracing }\end{array}$ \\
\hline $100 \%$ & 9.78 & 4.78 & 5.01 & 823 & 1178 \\
\hline $75 \%$ & 9.52 & 4.78 & 5.01 & 835 & 1178 \\
\hline $50 \%$ & 9.05 & 4.78 & 5.01 & 856 & 1178 \\
\hline
\end{tabular}

Table 4: Effective buckling length of the top chord of a $9 \mathrm{~m}$ span truss for various speed brace to top chord nail stiffness 


\begin{tabular}{|c|c|c|c|c|c|}
\hline $\begin{array}{c}\text { Percentage of short } \\
\text { duration mean nail } \\
\text { stiffness }\end{array}$ & $\begin{array}{c}\text { Lambda, } \\
\lambda_{\text {cr }} \\
\text { Speed } \\
\text { brace }\end{array}$ & $\begin{array}{c}\text { Lambda, } \\
\lambda_{\text {cr }} \\
\text { Diagonal } \\
\text { brace }\end{array}$ & $\begin{array}{c}\text { Force in } \\
\text { compression } \\
\text { member, P }(\mathrm{kN})\end{array}$ & $\begin{array}{c}\text { Top chord buckling } \\
\text { Length, KL (mm) } \\
\text { Speed Brace } \\
K L=\sqrt{\frac{\pi^{2} E I}{\lambda_{c r} P}}\end{array}$ & $\begin{array}{c}\text { Top chord buckling } \\
\text { Length, KL (mm) } \\
\text { Diagonal bracing }\end{array}$ \\
\hline $100 \%$ & 5.19 & 4.01 & 7.90 & 900 & 1024 \\
\hline $75 \%$ & 5.07 & 4.01 & 7.90 & 911 & 1024 \\
\hline $50 \%$ & 4.84 & 4.01 & 7.90 & 932 & 1024 \\
\hline
\end{tabular}

Table 5: Effective buckling length of the top chord of a $12 \mathrm{~m}$ span truss for various speed brace to top chord nail stiffness

From the analyses, using Prokon, 2012, [9] it is also possible to obtain an estimated buckled shape for roof using speed bracing and roofs using traditional diagonal bracing. The buckled shape of the $9 \mathrm{~m}$ span truss is shown in Figures 8 and 9, and the buckled shape for the $12 \mathrm{~m}$ span in Figures 10 and 11.

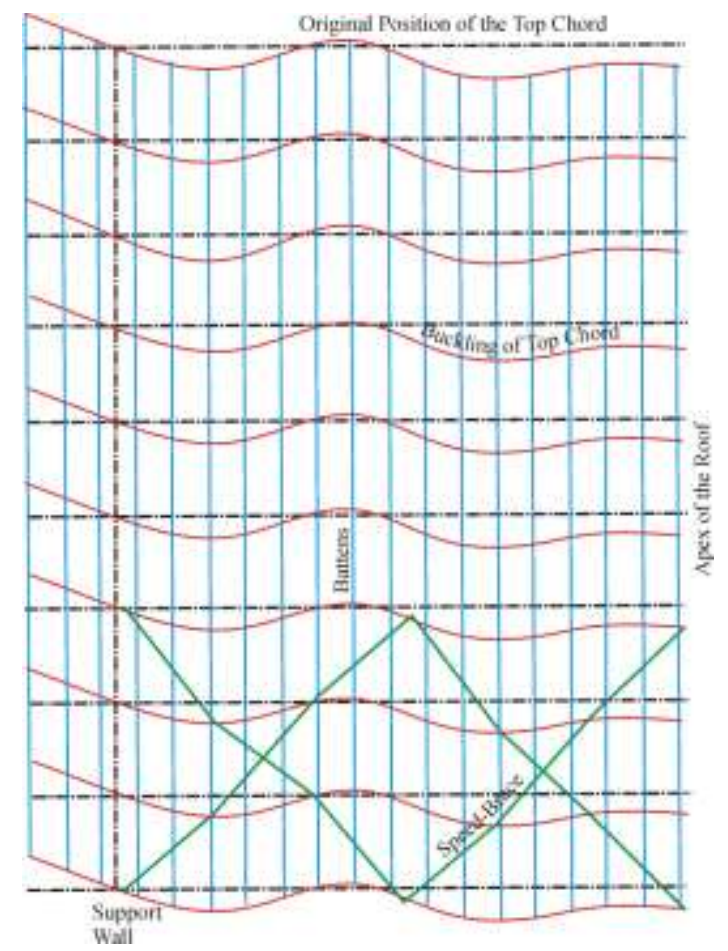

Figure 8: Buckled shape of the top chord - $9 \mathrm{~m}$ span trusses. Only half of the roof is shown as the roof and loading are symmetrical about the apex. 


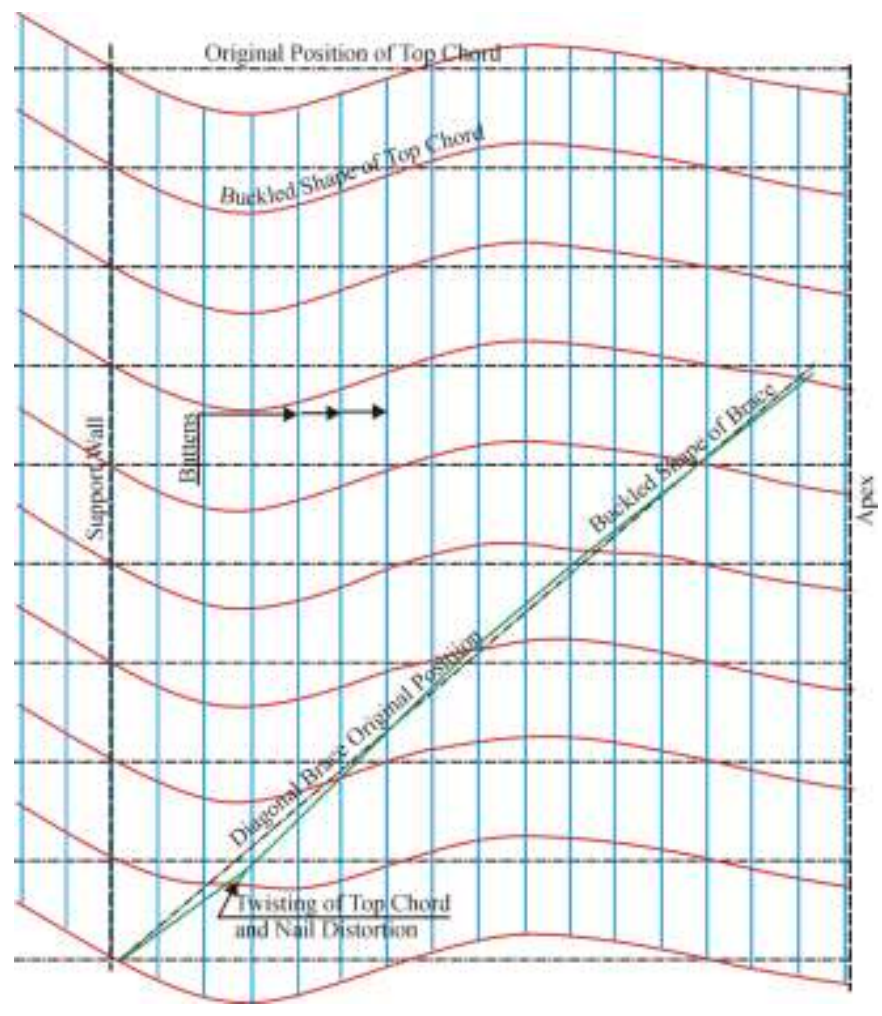

Figure 9: Buckled shape of top chords, $9 \mathrm{~m}$ span, using $36 \mathrm{~mm} \times 73 \mathrm{~mm}$ diagonal brace.

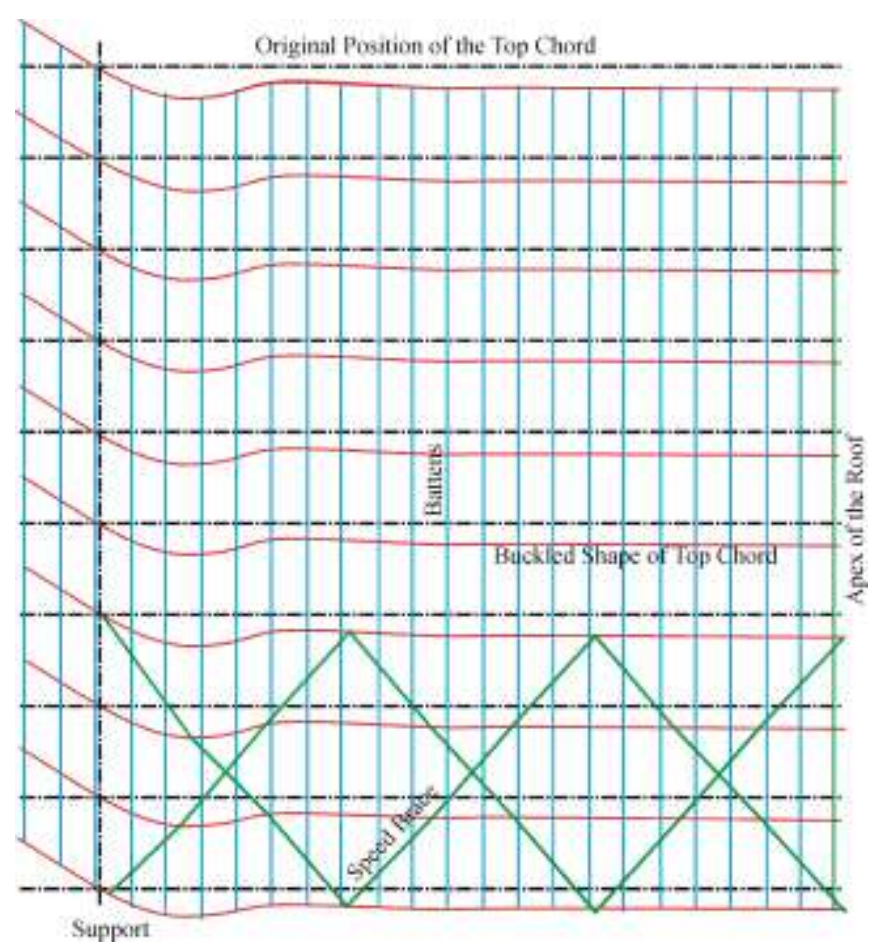

Figure 10: Buckled shape of the top chord - $12 \mathrm{~m}$ span trusses. Only half of the roof is shown as the roof and loading are symmetrical about the apex. 


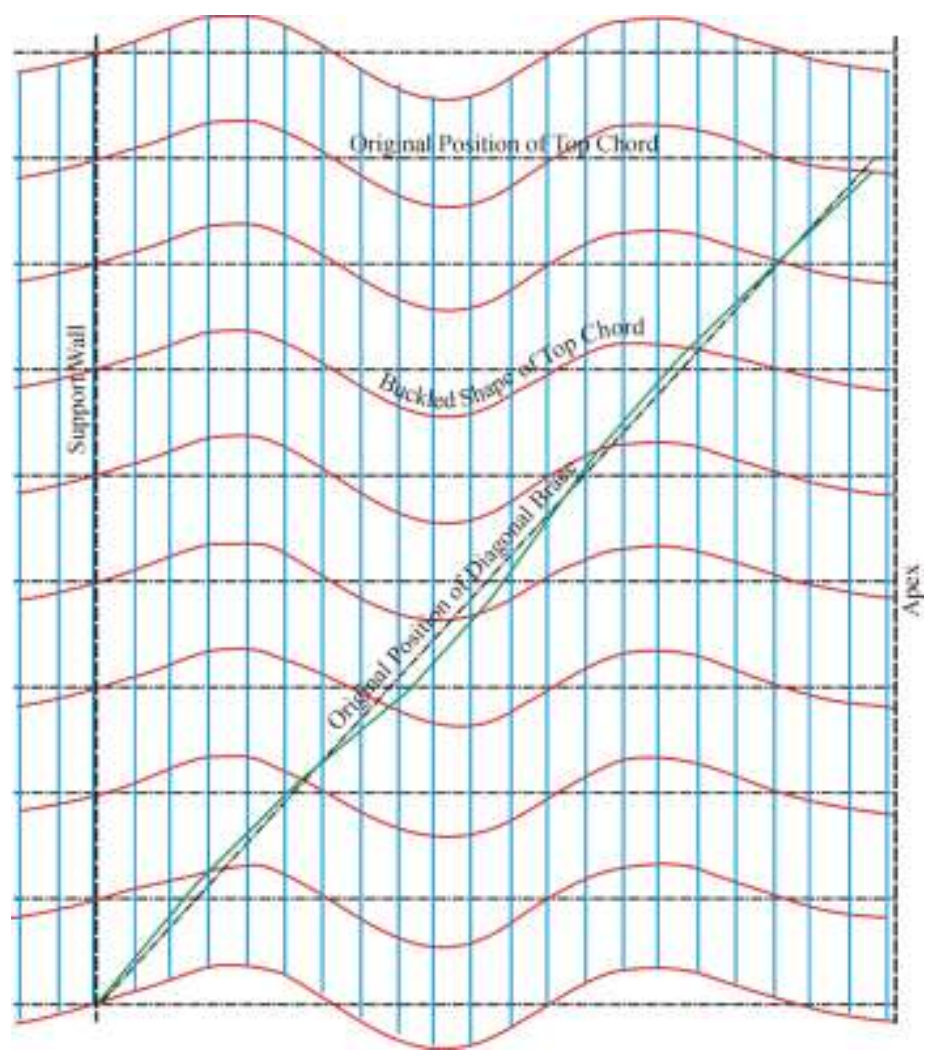

Figure 11: Buckled shape of top chords, $12 \mathrm{~m}$ span, using $36 \mathrm{~mm} \times 111 \mathrm{~mm}$ diagonal brace.

\section{Conclusion}

It is possible to draw a number of conclusions from the analyses presented in this paper especially if the numerous analyses by Burdzik and Dekker (2012) [3] on diagonal bracing are taken into account.

It makes sense that if the bracing system is placed between the compression members and the battens, which provide the bracing to trusses away from the cross-brace, a stiffer system will result. A stiff system will also ensure that the buckling length is as short as possible and that the force in the brace will be small, Salmon and Johnson (1990) [8]. The diagonal brace, as shown in Figure 1, is as far as one can place a brace away from the battens and still connect it to the compression member. Forces are transferred through the compression member in torsion, with the compression chord having low torsional rigidity. Burdzik and Dekker (2012) [3], showed that the buckling length of the top 
chord for $7,5 \mathrm{~m}$ and $10 \mathrm{~m}$ span trusses that were braced by means of diagonal braces was in the region of $1,1 \mathrm{~m}$. The effective buckling length for the top chord of $9 \mathrm{~m}$ span trusses, braced by means of speed-brace was in the region of $830 \mathrm{~mm}$ and for the $12 \mathrm{~m}$ span, $910 \mathrm{~mm}$. The speed-brace is therefore a better bracing system.

The theoretical effective buckling lengths are not very sensitive to the stiffness of the speed-brace to top chord connection. It appears as if the buckling length increases with the span of the truss even though the lateral stiffness of the top chords of the two truss spans was the same. If one compares Figures 7 and 8 it appears as if the buckled shape is tending towards single curvature as the span length increases. For spans larger than $12 \mathrm{~m}$ the size of the top chord will increase and the lack of torsional rigidity may play a bigger part in the buckling length as the distance between the brace and the centreline of the compression member increases.

It would be unwise to use a buckling length that is less than the spacing of the trusses divided by the cosine of the pitch of the roof and even that may not be conservative. One should bear in mind that the analyses used in this paper are idealized in that the assumption is made that all the nails are in place and placed correctly. The SANS10163:Part1 (2003) [10] rule which states that a minimum effective length of 15 times the lateral dimension of the compression member should be used, may not be critical for short spans (less than $9 \mathrm{~m}$ ) but may become problematic for larger spans (more than $9 m)$.

American National design standard for metal plate connected wood truss construction [14], and Mitek Fixing and Bracing guidelines [15] used in Australia, New Zealand and South-East Asia show bracing methods but are silent on the design buckling length of the top compression chord. The Eurocode 5 [7]; [16] has stiffness criteria, but once again does not give design buckling lengths.

It is prudent to remember that the actual structure may not behave quite as well as there is a big difference between the idealised structure and the actual assembled structure. Nails are often left out, the trusses are not perfectly plumb and the stiffness of the members may vary greatly in the truss. If a centreline analysis is used the model must closely resemble the actual structure in that the distance between the centreline of the battens, the brace and the top chord as well as the torsional flexibility of the truss members is taken into account. 


\section{References}

[1] BOSCH H, Shear resistance and stiffness of $75 \mathrm{~mm}$ nails in timber members. Report as part of uncompleted PhD, University of Pretoria, 2001.

[2] BURDZIK WMG, Effective stiffness of nailed multiple-ply timber members. Journal of the South African Institution of Civil Engineers, Vol 48, No 4, December 2006.

[3] BURDZIK WMG and DEKKER NW, A rational approach to predicting the buckling length of compression chords in prefabricated timber truss roof structures braced by means of diagonal bracing. Journal of the South African Institution of Civil Engineers, Vol 54, No 1, April 2012.

[4] BURDZIK, WMG and NKWERA, PD, The relationship between torsional rigidity and bending strength characteristics of S A pine, South African Forestry Journal - No 198, July 2003.

[5] COATES RC, COUTIE MG and KONG FK, 1988, Structural Analysis, Second Edition, Thomas Nelson and Sons Ltd, Great Britain.

[6] DEKKER, NW, BURDZIK, WMG, A Rational Approach to Obtaining Effective Lengths of Compression Members in Framed Structures. Journal of the South African Institution of Civil Engineers, Vol 47, No 2, 2005.

[7] EUROCODE 5. Design of timber structures. Part 1: General Rules and Rules for Buildings. NVN-ENV 2003-1-1

[8] SALMON, C.G and JOHNSON, J.E, 1990. Steel Structures, design and behaviour, Chapter 9, Paragraph 9.3, Third Edition, Harper Collins Publishers, New York, United States of America, ISBN 006-045703-1

[9] Prokon Software Consultants Ltd, PROKON suite of structural analysis programs, Pretoria, South Africa, 2012.

[10] SOUTH AFRICAN NATIONAL STANDARDS, SANS 10163-1:2003, The structural use of timber, Part 1: Limit-states design, Pretoria, South Africa. 
[11] SOUTH AFRICAN NATIONAL STANDARDS, SANS 10163-2:2001, The structural use of timber, Part 2: Allowable stress design, Pretoria, 2001.

[12] SOUTH AFRICAN NATIONAL STANDARDS, SANS 10243:2004, The manufacture and erection of timber trusses, Pretoria, 2004.

[13] SOUTH AFRICAN NATIONAL STANDARDS, SANS 1010160:2001, Structural loading, Pretoria, 2004.

[14] AMERICAN NATIONAL STANDARD, BSR/TPI 1-2002, National design standard for metal plate connected wood truss construction, 2002.

[15] MITEK, Fixing and bracing guidelines for timber roof trusses, 2009.

[16] MANUAL FOR THE DESIGN OF TIMBER BUILDING STRUCTURES TO EUROCODE 5, TP/06/31. 